\title{
Expression of IGFBP-6 in proliferative vitreoretinopathy rat models and its effects on retinal pigment epithelial-J cells
}

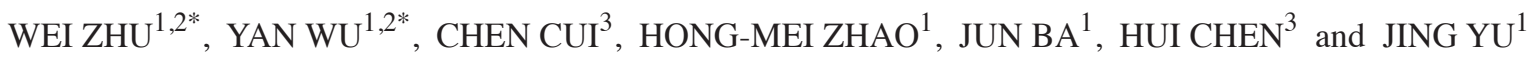 \\ ${ }^{1}$ Department of Ophthalmology, Shanghai Tenth People's Hospital, Tongji University School of Medicine, Shanghai 200072; \\ ${ }^{2}$ Department of the First Clinical Medical College, Nanjing Medical University, Nanjing, Jiangsu 210029; \\ ${ }^{3}$ Department of Ophthalmology, Affiliated Hospital of Nantong University, Nantong, Jiangsu 226001, P.R. China
}

Received June 19, 2013; Accepted October 28, 2013

DOI: $10.3892 / \mathrm{mmr} .2013 .1794$

\begin{abstract}
Proliferative vitreoretinopathy (PVR) is one of the most common causes for failed retinal detachment surgeries. The aim of the present study was to investigate the role of insulin-like growth factor-binding protein-6 (IGFBP-6) in PVR using rat models and its effects on retinal pigment epithelial-J (RPE-J) cells. PVR Wistar rat models were administered intravitreal injection of RPE-J cells $\left(1 \times 10^{6} / 5 \mu \mathrm{l}\right)$ combined with platelet-rich plasma $\left(1 \times 10^{7} / 5 \mu \mathrm{l}\right)$. The concentration of IGFBP-6 in the vitreous and serum of rats was tested by an enzyme-linked immunosorbent assay and the expression of IGFBP-6 mRNA in the liver and retina of rats was determined by quantitative polymerase chain reaction (qPCR). The expression of IGFBP-6 mRNA in the RPE-J cells stimulated by vitreous or serum from PVR patients or normal volunteers was also determined by qPCR. The proliferation of RPE-J cells was evaluated by the 3-(4,5-dimethylthiazol-2-yl)-5-(3-carboxymethoxyphenyl) -2-(4-sulfophenyl)-2H-tetrazolium, inner salt (MTS) method. The success rate of PVR rat model induction at the 8 th week was $89.5 \%$ (34/38). The concentration of IGFBP-6 in the vitreous and serum of PVR rats was significantly higher than that of the control group $(\mathrm{P}<0.05)$. The expression of IGFBP-6 mRNA in the retina of PVR rats was also significantly higher compared with the control group $(\mathrm{P}<0.05)$. The vitreous from PVR patients and donors significantly stimulated the expression of IGFBP-6 mRNA in the RPE-J cells ( $\mathrm{P}<0.05)$. IGFBP-6 only inhibited IGF-II-stimulated proliferation but not the basal level of proliferation or the PDGF/VEGF-stimulated RPE-J cell proliferation. Thus, the trends and effects of IGFBP-6 provide the possibility of PVR therapeutic targets, with the
\end{abstract}

Correspondence to: Professor Jing Yu, Department of Opthalmology, Affiliated Tenth People's Hospital of Tongji University, 301 Middle Yanchang Road, Shanghai 200072, P.R. China E-mail: dryujing@yahoo.com.cn

*Contributed equally

Key words: proliferative vitreoretinopathy, insulin-like growth factor-binding protein-6, growth factor, animal model, retinal pigmented epithelial-J cells vitreous representing a significant environmental factor in the progression of PVR.

\section{Introduction}

Proliferative vitreoretinopathy (PVR) is essentially an excessive wound-healing response mediated by the proliferation of many types of cells inside the vitreous cavity and on the surface of the retina, resulting in membrane formation and traction on the retina $(1,2)$. It is one of the most common causes for failed retinal detachment surgeries, and it develops in $5-10 \%$ of all retinal detachments $(3,4)$. The management of this situation is complicated further due to the capability of PVR to result in the detachment of otherwise successfully reattached retinas or even cause new breaks, necessitating additional corrective surgeries. The pathogenesis of PVR is not completely understood, but it is widely accepted that PVR is a phenomenon involving the migration, proliferation, and connective tissue production by a variety of cells that gain access to the vitreous cavity $(5,6)$. In addition, the various types of cells involved in PVR, immunohistochemical and ultrastructural studies have consistently reported the presence of retinal pigment epithelial (RPE) cells in fibrocellular scars $(7,8)$. Animal model experiments have demonstrated the ability of RPE cells to cause tractional retinal detachment, which supports the pathogenic role of RPE cells $(9,10)$. Previous studies on RPE cell behavior in vitro suggested numerous growth factors (GF), including platelet-derived GF (PDGF), vascular endothelial GF (VEGF), transforming GF, insulin-like GF (IGF), fibroblast GF and epidermal GF, as promoters of key cellular activities (11-15).

In a previous proteomic study, insulin-like growth factor-binding protein-6 (IGFBP-6) was one of 24 specific vitreous proteins shared between moderate and severe PVR samples (16). Experiments were designed to verify whether a similar correlation could be observed in the PVR rat models and to investigate the mechanisms of IGFBP-6 expression in PVR.

\section{Materials and methods}

The present study was conducted in compliance with the ARVO Statement for the Use of Animals in Ophthalmic and Vision Research. The animal experiments were performed 
under the protocols approved by the National Eye Institute Institutional Animal Care and Use Committee. The present study also followed the tenets of the Declaration of Helsinki for the use of human subjects.

RPE-J cell preparation and culture. RPE-J cells (CRL-2240, ATCC, Rockville, MD, USA) were a generous gift from Lian-Fang Du (Department of Medical Ultrasound, Shanghai Jiaotong University Affiliated First People's Hospital, Shanghai, China). The cells were cultured in Dulbecco's modified Eagle's medium with $4 \%$ fetal bovine serum and $1 \%$ antibiotic/antimycotic (all from Gibco, Grand Island, NE, USA) at $37^{\circ} \mathrm{C}$ with $5 \% \mathrm{CO}_{2}$. The cells used in the 3-(4,5-dimethylthiazol-2-yl)-5(3-carboxymethoxyphenyl)-2-(4-sulfophenyl)-2H-tetrazolium, inner salt (MTS) proliferation assay were cultured in a humidified incubator.

The cells used for rat model induction were inoculated in a six-well plate at a concentration of $2 \times 10^{4} / \mathrm{cm}^{2}$ and maintained in complete medium for $24 \mathrm{~h}$. Following adhesion of the cells, the medium was switched to serum-free medium for $24 \mathrm{~h}$.

Induction of rat models. Seventy-six male adult Wistar rats (Shanghai Slac laboratory animal Co. Ltd., Shanghai, China; weight, $200 \pm 10 \mathrm{~g}$; age, 7 weeks; specific pathogen-free) were included in the present study, and they were divided into a PVR $(n=40)$ and a control group $(n=36)$. The PVR Wistar rat models were established as previously described (17). In brief, hyaluronidase $(1 \mathrm{U})$ was injected into the vitreous cavity to liquefy the vitreous, and RPE-J cells $\left(1 \times 10^{6} / 5 \mu \mathrm{l}\right)$ and platelet-rich plasma (PRP) $\left(1 \times 10^{7} / 5 \mu \mathrm{l}\right)$ were injected into the vitreous cavity of rats to induce PVR. Sterile pyrogen-free normal saline was injected into the vitreous cavity in the control group.

The rats were observed by slit lamp, fundus examination and photography at 1,2,4 and 8 weeks after intravitreal injection. Rats with any anterior segment inflammation, vitreous hemorrhage or cataracts were excluded from the present study. Tissues of the PVR ( $\mathrm{n}=10,8,10$ and 6$)$ and control $(\mathrm{n}=10,10$, 10 and 6) groups were collected at 1,2, 4 and 8 weeks after model induction, respectively. The proliferative response was evaluated according to the following grading scale (18): 0 , no proliferative response; 1 , intravitreal proliferation; 2 , epiretinal membrane formation with retinal folds and 3 , white dense membrane covering the retina, with retinal folds and localized retinal detachments with or without a localized posterior capsular cataract.

\section{Collection of tissues and sample preparation}

Liver. The livers of Wistar rats were isolated immediately after anesthesia with Napental. In total, $200 \mathrm{mg}$ liver tissue was stored in a $1.5 \mathrm{ml}$ centrifuge tube at $-80^{\circ} \mathrm{C}$.

Serum. Venous blood $(2 \mathrm{ml})$ was collected from the rats from the abdomen cardinal vein and placed in a procoagulant tube at room temperature for $1 \mathrm{~h}$. The blood was centrifuged at $4^{\circ} \mathrm{C}$ at $7,000 \mathrm{xg}$ for $5 \mathrm{~min}$. The supernatant was stored at $-80^{\circ} \mathrm{C}$.

Vitreous. The vitreous was placed in a $1.5 \mathrm{ml}$ centrifuge tube following isolation and centrifuged at $4^{\circ} \mathrm{C}$ at $13,400 \mathrm{x}$ g for $5 \mathrm{~min}$. The supernatant was stored at $-80^{\circ} \mathrm{C}$.

Retina. The retina was placed in a $1.5 \mathrm{ml}$ centrifuge tube at $-80^{\circ} \mathrm{C}$.
Effect of cytokines on IGFBP-6 mRNA expression in RPE-J cells. The groups were divided as follows: the control, which contained no growth factors; the IGF-II, which contained 10, 20 or $50 \mathrm{ng} / \mathrm{ml}$ IGF-II; the VEGF, which contained 10,20 or $40 \mathrm{ng} / \mathrm{ml}$ VEGF and the PDGF, which contained 10, 20 or 40 ng/ml PDGF.

Effect of vitreous and serum on IGFBP-6 $\mathrm{mRNA}$ expression in RPE-J cells. Vitreous and serum samples of PVR patients with primary rhegmatogenous retinal detachment from the Department of Ophthalmology, Nantong University Affiliated Hospital, were used in the present study. Patients with ocular trauma, age-related macular degeneration, uveitis, glaucoma, diabetes mellitus, a history of ocular surgery or other systemic diseases were excluded. Informed consent was obtained from all the patients following verbal and written explanation of the nature and possible consequences of the present study. PVR was graded in accordance with the standards of the Committee TRST in 1983 (19) and evaluated by at least three associate chief or chief surgeons. Severe PVR (grade $\mathrm{C}$ or $\mathrm{D}, \mathrm{n}=5$ ) and moderate PVR (grade $\mathrm{B}, \mathrm{n}=5$ ) (20) were included in the present study. Undiluted $0.3-1.0 \mathrm{ml}$ vitreous humor samples were obtained from patients with a syringe by aspirating liquefied vitreous from the center of the vitreous cavity prior to the vitrectomy infusion. The corresponding serum samples were obtained prior to surgery.

The control group of normal human eyes without any known ocular diseases $(\mathrm{n}=5)$, which were donated for corneal transplant in accordance with the standardized rules for the development and applications of organ transplants, was obtained from the Organ Transplant Center in Shanghai (Shanghai, China). In total, 0.8-1.0 $\mathrm{ml}$ of normal vitreous samples were aspirated with a syringe from the pars plana. The normal serum samples were obtained from five healthy volunteers who underwent a physical examination at the Shanghai Tenth People's Hospital; these volunteers had no ocular or systemic diseases.

Harvested vitreous humor samples were collected in Eppendorf tubes (Axygen, Union City, CA, USA), immediately placed on ice, centrifuged for $15 \mathrm{~min}$ at $12,000 \mathrm{rpm}$ to separate the cell contents and stored at $-80^{\circ} \mathrm{C}$ until use. The serum samples were placed at room temperature for $1 \mathrm{~h}$, centrifuged for $15 \mathrm{~min}$ at $-4^{\circ} \mathrm{C}$ and stored at $-80^{\circ} \mathrm{C}$. The demographic characteristics of the samples obtained from the donors are shown in Table I. There was no significant difference among the groups $(\mathrm{P}>0.05)$.

Quantitative polymerase chain reaction $(q P C R)$. Total RNA was isolated from the retina of PVR rats and RPE-J cells as per the manufacturer's instructions (TRIzol ${ }^{\oplus}$; Invitrogen, Carlsbad, CA, USA). In total, $2 \mu \mathrm{g}$ RNA was converted into cDNA. The primer sequences (5'-3') were: IGFBP-6 (NM_013104): forward, 5'-GAAGAGACTACCAAGGAGAGCAAAC-3' and reverse, 3'-CTGCAGTACTGAATCCAAGTGTCT-5'; $\beta$-actin (NM_031144): forward, 5'-CCCATCTATGAGGGTTA CGC-3' and reverse, 3'-TTTAATGTCACGCAGATTTC-5'. The qPCR assays were performed according to the manufacturer's instructions.

Enzyme-linked immunosorbent assay for IGFBP-6 measurement in rats. The IGFBP- 6 concentration was measured 
Table I. Demographic characteristics of the samples.

\begin{tabular}{lcccccc}
\hline Characteristics & $\mathrm{N}$ & Vitreous & Serum & Age, years & Gender (male/female) & Eye (right/left) \\
\hline Moderate PVR & 5 & + & + & $57.8 \pm 5.8$ & $2 / 3$ & $3 / 2$ \\
Severe PVR & 5 & + & + & $56.4 \pm 5.4$ & $3 / 2$ & $3 / 2$ \\
Normal donors & 5 & + & - & $58.2 \pm 8.3$ & $2 / 3$ & - \\
Healthy volunteers & 5 & - & + & $56.2 \pm 4.3$ & & \\
\hline
\end{tabular}

PVR, proliferative vitreoretinopathy.

Table II. Results of the PVR rat model induction.

\begin{tabular}{lcccc}
\hline Variables & 1 weeks & 2 weeks & 4 weeks & 8 weeks \\
\hline Grade 0 & 20 & 13 & 6 & 4 \\
Grade 1 & 15 & 14 & 5 & 5 \\
Grade 2 & 3 & 9 & 10 & 8 \\
Grade 3 & 0 & 2 & 17 & 21 \\
PVR rate, \% & 47.4 & 65.8 & 84.2 & 89.5 \\
\hline
\end{tabular}

PVR, proliferative vitreoretinopathy.

in the serum and vitreous of rats with an enzyme-linked immunosorbent assay kit (Millipore, Billerica, MA, USA) at 8 weeks following intravitreous injection. All procedures were conducted according to the manufacturer's instructions.

MTS proliferation assay. The RPE-J cells were counted by the MTS assay, which relies on the formation of a colored substrate by mitochondrial enzyme activity in viable cells. The cells were plated in a 96-well plate in growth medium and allowed to attach overnight (2,000 per well). Following washing twice with phosphate-buffered saline, the cells were switched to serum-free media and left overnight at $37^{\circ} \mathrm{C}$. The cells were incubated in serum-free medium with or without $50 \mathrm{ng} / \mathrm{ml}$ IGF-II (R\&D Systems, MN, USA) at $37^{\circ} \mathrm{C}$ for 24 or $48 \mathrm{~h}$. Variable concentrations of 1,10,100,500 and 1,000 ng/ml recombinant human IGFBP-6 (R\&D Systems) were added to the cells. MTS (20 $\mu \mathrm{l}$ per well) was then added for $3 \mathrm{~h}$. The absorbance was measured with a plate reader (Molecular Devices, Sunnyvale, CA, USA) at $490 \mathrm{~nm}$.

Statistical analysis. Statistical analysis was performed using SPSS (version 14.0, SPSS, Inc., Chicago, IL, USA). The results were expressed as the mean \pm standard deviation (SD). Multiple comparisons within the experimental groups were performed using a one-way analysis of variance, and comparisons between the two groups were performed using independent group t-tests. $\mathrm{P}<0.05$ was used to indicate a statistically significant difference.

\section{Results}

In vivo results of the PVR rat model induction. Two rats were excluded due to cataracts in the PVR group in the 1st week after intravitreal injection. The success rate of the PVR rat

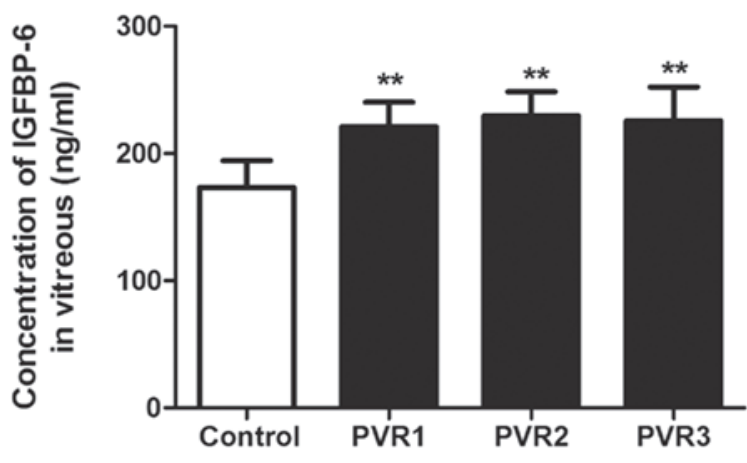

Figure 1. The expression of IGFBP-6 221.00 $\pm 19.32,229.63 \pm 18.89$ and $225.70 \pm 26.71 \mathrm{ng} / \mathrm{ml}$ in vitreous of PVR grade 1, 2 and 3, respectively, was significantly higher than $173.25 \pm 21.11 \mathrm{ng} / \mathrm{ml}$ in the control group $(\mathrm{P}<0.05)$. $\left({ }^{* *} \mathrm{P}<0.01\right.$ vs. control group).PVR, proliferative vitreoretinopathy.

models at the 8 th week was $89.5 \%$ (34/38). In total, 15 grade one and three grade two PVR rat models were observed at the 1st week subsequent to intravitreal injection. At the 2nd week, two grade three PVR rat models were observed. More grade two and three PVR rat models were observed at the 4th week. At the 8th week, there were five, eight and 21 rat models at PVR grades one, two and three, respectively (Table II).

In vivo IGFBP-6 concentration in the vitreous and serum of rat models

IGFBP-6 in general samples. The IGFBP-6 concentration $(225.44 \pm 19.36 \mathrm{ng} / \mathrm{ml})$ in the vitreous of the PVR rat models was significantly higher than $173.25 \pm 21.11 \mathrm{ng} / \mathrm{ml}$ concentration in the control group $(\mathrm{P}=0.003)$. The concentration of IGFBP-6 in the serum of the PVR group was higher than that in the control group $(\mathrm{P}=0.012)$.

IGFBP- 6 in the different $P V R$ grades. The IGFBP- 6 concentrations $221.00 \pm 19.3,229.63 \pm 18.89$ and $225.70 \pm 26.71 \mathrm{ng} / \mathrm{ml}$ in the vitreous of PVR grades 1, 2 and 3, respectively, was significantly higher than that in the control group $(\mathrm{P}<0.01)$. However, there was no significant difference among the three PVR grade groups $(\mathrm{P}=0.892)$ (Fig. 1).

Comparison of IGFBP-6 between vitreous and serum. In normal rats, the concentration of $173.25 \pm 21.11 \mathrm{ng} / \mathrm{ml}$ IGFBP-6 was significantly higher in the vitreous compared with $95.96 \pm 17.40 \mathrm{ng} / \mathrm{ml}$ in the serum $(\mathrm{P}=0.000)$. Similarly, in the PVR rat models, the concentration of $225.44 \pm 19.36$ $\mathrm{ng} / \mathrm{ml}$ IGFBP-6 in the vitreous was significantly higher compared with $108.48 \pm 15.78 \mathrm{ng} / \mathrm{ml}$ in the serum $(\mathrm{P}=0.000)$. 
Table III. The expression of IGFBP-6 mRNA in retina of rats $\left(2^{-\Delta \mathrm{CT}} \times 10^{-4}\right)($ mean $\pm \mathrm{SD})$.

\begin{tabular}{lccccr}
\hline Variables & 1 weeks & 2 weeks & 4 weeks & 8 weeks & In general \\
\hline Control group & $8.85 \pm 2.32$ & $8.37 \pm 2.59$ & $8.32 \pm 2.96$ & $8.18 \pm 1.81$ & $8.32 \pm 2.41$ \\
PVR group & $10.03 \pm 2.55$ & $11.02 \pm 2.92$ & $11.62 \pm 2.33$ & $11.82 \pm 2.27$ & $11.09 \pm 2.57$ \\
P-value & 0.293 & 0.058 & 0.013 & 0.009 & 0.000 \\
\hline
\end{tabular}

IGFBP-6, insulin-like growth factor-binding protein-6; PVR, proliferative vitreoretinopathy; SD, standard deviation.

Table IV. The expression of IGFBP-6 mRNA in retina and liver of different grade PVR rat models $\left(2^{-\Delta \mathrm{CT}} \mathrm{X} 10^{-4}\right)$.

\begin{tabular}{lrrrr}
\hline & \multicolumn{2}{c}{ Retina } & \multicolumn{2}{c}{ Liver } \\
\cline { 2 - 3 } \cline { 5 - 5 } Group & Mean $\pm \mathrm{SD}$ & P-value & Mean \pm SD & P-value \\
\hline Control & $8.32 \pm 2.41$ & & $25.01 \pm 12.04$ & 0.999 \\
PVR 1 & $10.87 \pm 2.77$ & 0.035 & $27.58 \pm 18.98$ & 0.982 \\
PVR 2 & $11.35 \pm 2.45$ & 0.003 & $21.92 \pm 11.94$ & 0.477 \\
PVR 3 & $11.07 \pm 2.67$ & 0.000 & $31.41 \pm 11.07$ & \\
\hline
\end{tabular}

IGFBP-6, insulin-like growth factor-binding protein-6; PVR, proliferative vitreoretinopathy; SD, standard deviation.

It was increased to a higher extent in the vitreous than in the serum.

In vivo results of $q P C R$ in rats.

After measuring the cycle threshold (CT) value of each sample, the $\triangle \mathrm{CT}$ was determined by subtracting the CT value of $\beta$-actin from IGFBP-6. The relative amount of IGFBP-6 expression was calculated as $2^{-\Delta \mathrm{CT}}$ and presented as $2^{-\Delta \mathrm{CT}} \times 10^{-4}$ due to the low value.

Expression of IGFBP- $6 \mathrm{mRNA}$ in the retina. In general, the expression of IGFBP-6 mRNA in the retina and of IGFBP-6 of each grade of the PVR group was higher compared with that of the control group $(\mathrm{P}=0.000$; Table III and $\mathrm{P}<0.05$, respectively). However, there was no significant difference among the different grades of PVR ( $>>0.05$; Table IV).

Expression of IGFBP-6 $m R N A$ in the liver. In the PVR group, no significant difference was observed in the expression of IGFBP- 6 mRNA in the liver at different times $(\mathrm{P}>0.05)$. No difference was found between the PVR and control groups at any time points $(\mathrm{P}=0.443)$ and there was no significant difference among the different grades of PVR (P>0.05; Table IV).

In vitro effects of IGFBP-6 on RPE-J cell proliferation. After the RPE-J cells were incubated with $50 \mathrm{ng} / \mathrm{ml}$ exogenous IGF-II for 24 or $48 \mathrm{~h}$, the OD value, which reflected the cell number, increased significantly $(24 \mathrm{~h}$ : from $1.26 \pm 0.05$ to $1.38 \pm 0.05$ and $48 \mathrm{~h}$ : from $1.14 \pm 0.05$ to $1.44 \pm 0.06 ; \mathrm{P}<0.05)$. When $500 \mathrm{ng} / \mathrm{ml}$ IGFBP-6 was added to the DMEM plates for $3 \mathrm{~h}$, the OD value was significantly reduced to $1.23 \pm 0.04$ and $1.30 \pm 0.05$, respectively $(\mathrm{P}<0.01)$. However, there was no significant difference following IGFBP-6 treatment in the VEGF or PDGF groups. IGFBP-6 alone had no effect on basal proliferation ( $\mathrm{P}>0.05$; Fig. 2).

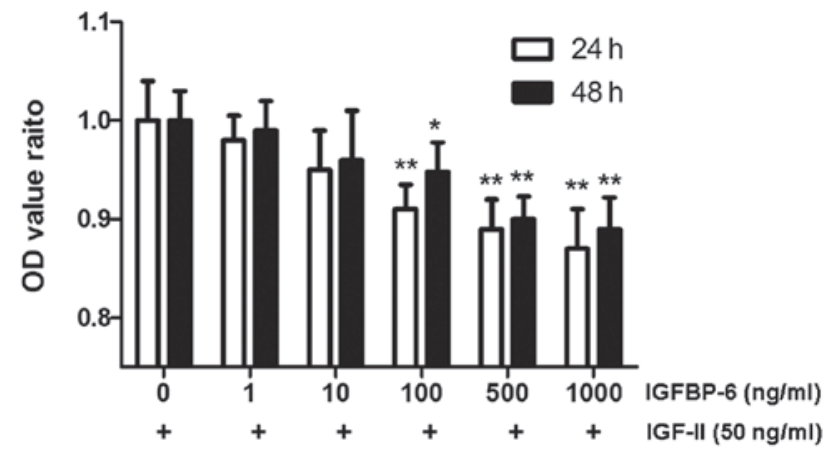

Figure 2. Effects of IGFBP-6 on the proliferation of RPE-J cells were induced by IGF-II. Optical density (OD) value ratio=OD value in the PVR group/OD value in the control group. The RPE-J cells in all the groups were treated with $50 \mathrm{ng} / \mathrm{ml} \mathrm{IGF-II} \mathrm{for} 24$ or $48 \mathrm{~h}$ to induce cell proliferation, then different doses of IGFBP- 6 were added to the media incubated for $3 \mathrm{~h}$. RPE-J cell was treated without IGFBP- 6 in the control group. $\left({ }^{*} \mathrm{P}<0.05\right.$ and ${ }^{* *} \mathrm{P}<0.01$ vs. control group). IGFBP-6, insulin-like growth factor-binding protein-6; RPE-J, retinal pigment epithelial-J PVR, proliferative vitreoretinopathy.

In vitro effects of cytokines on IGFBP-6 mRNA expression in $R P E-J$ cells. At 20 and $50 \mathrm{ng} / \mathrm{ml}, \mathrm{IGF}-\mathrm{II}$ significantly stimulated the expression of IGFBP-6 mRNA, which was $1.07 \pm 0.08$-fold $(\mathrm{P}=0.036)$ and $1.08 \pm 0.05$-fold $(\mathrm{P}=0.020)$ higher compared with the control group. There was no significant difference between the IGF-II and control group at $10 \mathrm{ng} / \mathrm{ml}(\mathrm{P}>0.05)$. (Fig. 3)

Different concentrations of PDGF had no significant effect on the expression of IGFBP-6 mRNA. The fold changes were $1.002 \pm 0.061,0.997 \pm 0.080$ and $1.010 \pm 0.051$ at 10,20 and $50 \mathrm{ng} / \mathrm{ml}$, respectively $(\mathrm{P}>0.05)$.

As with PDGF, there was no significant difference between the VEGF and control group at 10, 20 and $50 \mathrm{ng} / \mathrm{ml}(\mathrm{P}>0.05)$. 


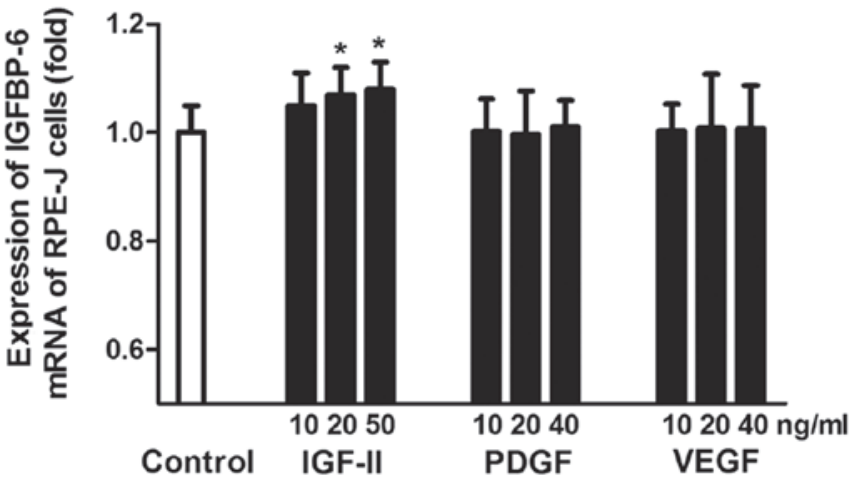

Figure 3. Effect of cytokines on IGFBP-6 mRNA expression of RPE-J cells The RPE-J cells were cultured with different concentrations of cytokines and the control group was cultured in normal serum-free medium. In total, 20 and $50 \mathrm{ng} / \mathrm{ml}$ of IGF-II significantly stimulated the expression of IGFBP-6 mRNA ( $\mathrm{P}=0.036$ and $\mathrm{P}=0.020$, respectively). (" $\mathrm{P}<0.05$ vs. control group). IGFBP-6, insulin-like growth factor-binding protein-6; RPE-J, retinal pigment epithelial-J; mRNA, messenger RNA.

In vitro effects of vitreous or serum on IGFBP-6 $m R N A$ expression in RPE-J cells. In general, the vitreous from PVR patients and donors significantly stimulated the expression of IGFBP-6 mRNA. The IGFBP-6 mRNA expression level in the RPE-J cells stimulated by vitreous from donors, moderate PVR and severe PVR groups was $1.72 \pm 0.33,1.83 \pm 0.29$ and $1.85 \pm 0.41$-fold higher, respectively, compared with the control group $(\mathrm{P}<0.01)$. However, there was no significant difference between the serum and control groups. The IGFBP- 6 mRNA level stimulated by serum from healthy volunteers, moderate PVR and severe PVR patient groups was $0.85 \pm 0.34,0.91 \pm 0.22$ and $0.88 \pm 0.42$-fold higher, respectively, compared with the control group ( $\mathrm{P}>0.05)$ (Fig. 4).

\section{Discussion}

In our previous proteomic study, 102 PVR-specific proteins were identified in the vitreous of PVR patients by two-dimensional-nano-liquid chromatography coupled with tandem mass spectrometry (16). Among these, 24 specific vitreous proteins were shared between moderate and severe PVR samples (16). In the previous study, IGFBP-6 was identified as a specific protein in the vitreous and serum of PVR patients. However, the contributions of IGFBP-6 to the PVR process remain unclear.

In the present study, a significantly higher concentration of IGFBP-6 was detected in the vitreous, serum and retina of the PVR rat models compared with the normal control rats. This result demonstrates that IGFBP-6 is a specific protein in the PVR process. The concentration of IGFBP- 6 in the vitreous was significantly higher compared with the serum, suggesting that the upregulated IGFBP-6 in the vitreous was not from the serum. No significant difference was found in the expression of IGFBP- 6 mRNA in the liver between the PVR and control groups. Due to IGFBP-6 being primarily produced in the liver (21), this result indicates that upregulated IGFBP-6 in the vitreous and serum was not from the liver. Additionally, the upregulated IGFBP- 6 was produced in a local autocrine or paracrine manner. Certain studies have

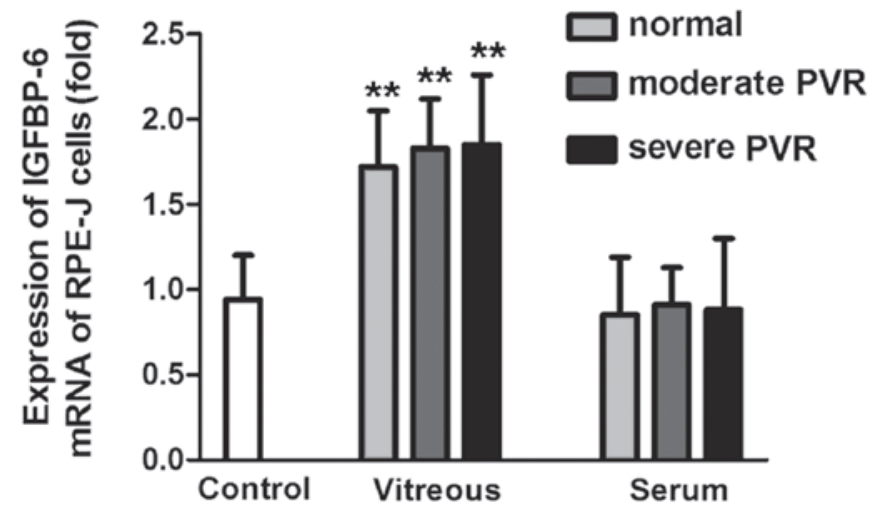

Figure 4. Effect of vitreous and serum on IGFBP-6 mRNA expression of the RPE-J cells. The vitreous significantly stimulated the expression of IGFBP-6 mRNA $(\mathrm{P}<0.01)$, while the serum did not affect the expression of IGFBP-6 mRNA $(\mathrm{P}>0.05)$. ( $* * \mathrm{P}<0.01$ vs. control group). IGFBP-6, insulin-like growth factor-binding protein-6; RPE-J, retinal pigment epithelial-J; mRNA, messenger RNA.

indicated that the choroids (22) and ciliary body (23) express IGFBP-6 mRNA, however, further investigations should be performed (23).

IGFBP-6 is a relatively novel member of the IGFBP family that inhibits proliferation and induces apoptosis in rhabdomyosarcoma cells (24) and suppresses striated muscle cell migration (25). Unlike other IGFBPs, the affinity of IGFBP-6 for IGF-II is $~ 50$-fold higher compared with the IGF-I (26). This characteristic makes IGFBP-6 a potent inhibitor of IGF-II, which is significant, in particular in inhibiting the growth of IGF-II-dependent tumors (27,28), including neuroblastoma (29), rhabdomyosarcoma (29) and colon carcinoma (30). IGF-II, an autocrine tumor growth factor, is a potent promoter of RPE cell tractional force generation in vitro (11). A previous study confirmed that IGF-II was expressed at higher levels in PVR patients (31). In the present study, the expression of IGFBP-6 mRNA in RPE-J cells was significantly upregulated by IGF-II at 20 and $50 \mathrm{ng} / \mathrm{ml}$, which may have been due to the increased level of IGF-II. Therefore, IGFBP-6 may downregulate RPE-J cell proliferation through inhibiting the actions of IGF-II.

In this study, IGFBP-6 inhibited the IGF-II-stimulated proliferation of RPE-J cells but not basal proliferation, suggesting that the basal growth of RPE-J cells is IGF-II independent under these conditions. The results indicate that IGFBP-6 is a potent anti-proliferative agent, and its anti-proliferative effects depend on its combination with IGF-II. Therefore, IGFBP-6 may be a novel target to control the PVR process.

In addition to IGFBP-6, other growth factors were upregulated in PVR patients, including PDGF (32) and VEGF (33), which are capable of inducing RPE-J cell proliferation and migration $(34,35)$. In the current study, these two growth factors were selected to evaluate the role of IGFBP-6 in the RPE-J cells. The final concentration used was based on previous studies that revealed their effect on the RPE-J cells. Neither PDGF nor VEGF had a significant effect on IGFBP-6 mRNA expression. Additionally, IGFBP-6 only inhibited IGF-II-stimulated but not PDGF- or VEGF-stimulated RPE-J cell proliferation, which indicated that the role of IGFBP-6 in RPE-J cell proliferation was independent of PDGF and VEGF. 
In the present study, the vitreous of PVR patients and donated eyes significantly stimulated the expression of IGFBP-6 mRNA in the RPE-J cells, while the serum had no effect on this expression. This result revealed that RPE-J cell proliferation in the PVR progression was dependent on the vitreous environment. The proliferation and migration of RPE-J cells are significant during the development of PVR. RPE-J cells usually remain in the G0 phase, with no proliferative or migratory activity in the normal state, until the retina is broken by trauma or surgery; subsequently, they gain access to the vitreous cavity or subretinal space and begin proliferating and migrating (36). Those data are in agreement with the results of the present study.

In summary, the trends and effects of IGFBP-6 may provide a possibility of a PVR therapeutic target, with the vitreous serving as a significant environmental factor in the progression of PVR.

\section{Acknowledgements}

This study was supported in whole or in part, by the National Nature Science Foundation Project (grant no. 30901643), Shanghai Science Committee Biology Department Pilot Project (grant no. 10411964900) and The New Excellence Project of Shanghai Health Bureau (grant no. XYQ2011067).

\section{References}

1. Pastor JC: Proliferative vitreoretinopathy: an overview. Sury Ophthalmol 43: 3-18, 1998.

2. Weller M, Wiedemann P and Heimann K: Proliferative vitreoretinopathy - is it anything more than wound healing at the wrong place? Int Ophthalmol 14: 105-117, 1990.

3. Girard P, Mimoun G, Karpouzas I and Montefiore G: Clinical risk factors for proliferative vitreoretinopathy after retinal detachment surgery. Retina 14: 417-424, 1994.

4. Pastor JC, de la Rúa ER and Martín F: Proliferative vitreoretinopathy: risk factors and pathobiology. Prog Retin Eye Res 21: 127-144, 2002.

5. Ryan SJ: The pathophysiology of proliferative vitreoretinopathy in its management. Am J Ophthalmol 100: 188-193, 1985.

6. Wiedemann P and Weller M: The pathophysiology of proliferative vitreoretinopathy. Acta Ophthalmol Suppl 189: 3-15, 1988.

7. Baudouin C, Hofman P, Brignole F, Bayle J, Loubière R and Gastaud P: Immunocytology of cellular components in vitreous and subretinal fluid from patients with proliferative vitreoretinopathy. Ophthalmologica 203: 38-46, 1991.

8. Vinores SA, Campochiaro PA and Conway BP: Ultrastructural and electron-immunocytochemical characterization of cells in epiretinal membranes. Invest Ophthalmol Vis Sci 31: 14-28, 1990.

9. Wong CA, Potter MJ, Cui JZ, et al: Induction of proliferative vitreoretinopathy by a unique line of human retinal pigment epithelial cells. Can J Ophthalmol 37: 211-220, 2002.

10. Yang CH, Huang TF, Liu KR, Chen MS and Hung PT: Inhibition of retinal pigment epithelial cell-induced tractional retinal detachment by disintegrins, a group of Arg-Gly-Asp-containing peptides from viper venom. Invest Ophthalmol Vis Sci 37: 843-854, 1996.

11. Mukherjee S and Guidry C: The insulin-like growth factor system modulates retinal pigment epithelial cell tractional force generation. Invest Ophthalmol Vis Sci 48: 1892-1899, 2007.

12. Spraul CW, Kaven C, Amann J, Lang GK and Lang GE: Effect of insulin-like growth factors 1 and 2 , and glucose on the migration and proliferation of bovine retinal pigment epithelial cells in vitro. Ophthalmic Res 32: 244-248, 2000.

13. Mitsuhiro MR, Eguchi S and Yamashita H: Regulation mechanisms of retinal pigment epithelial cell migration by the TGF-beta superfamily. Acta Ophthalmol Scand 81: 630-638, 2003.
14. Spraul CW, Kaven C, Lang GK and Lang GE: Effect of growth factors on bovine retinal pigment epithelial cell migration and proliferation. Ophthalmic Res 36: 166-171, 2004.

15. Hollborn M, Bringmann A, Faude F, Wiedemann P and Kohen L: Signaling pathways involved in PDGF-evoked cellular responses in human RPE cells. Biochem Biophys Res Commun 344: 912-919, 2006.

16. Yu J, Liu F, Cui SJ, et al: Vitreous proteomic analysis of proliferative vitreoretinopathy. Proteomics 8: 3667-3678, 2008.

17. Zheng XZ, Du LF and Wang HP: An immunohistochemical analysis of a rat model of proliferative vitreoretinopathy and a comparison of the expression of TGF- $\beta$ and PDGF among the induction methods. Bosn J Basic Med Sci 10: 204-209, 2010.

18. Behar-Cohen FF, Thillaye-Goldenberg B, de Bizemont $\mathrm{T}$, Savoldelli M, Chauvaud D and de Kozak Y: EIU in the rat promotes the potential of syngeneic retinal cells injected into the vitreous cavity to induce PVR. Invest Ophthalmol Vis Sci 41: 3915-3924, 2000.

19. No authors listed: The classification of retinal detachment with proliferative vitreoretinopathy. Ophthalmology 90: 121-125, 1983.

20. Yanyali A and Bonnet M: Risk factors of postoperative proliferative vitreoretinopathy in giant tears. J Fr Ophtalmol 19: 175-180, 1996 (In French).

21. Jones JI and Clemmons DR: Insulin-like growth factors and their binding proteins: biological actions. Endocr Rev 16: 3-34, 1995.

22. Burren CP, Berka JL, Edmondson SR, Werther GA and Batch JA: Localization of mRNAs for insulin-like growth factor-I (IGF-I), IGF-I receptor, and IGF binding proteins in rat eye. Invest Ophthalmol Vis Sci 37: 1459-1468, 1996.

23. Bergman PB, Moravski CJ, Edmondson SR, et al: Expression of the IGF system in normal and diabetic transgenic (mRen-2)27 rat eye. Invest Ophthalmol Vis Sci 46: 2708-2715, 2005.

24. Gallicchio MA, Kaun C, Wojta J, Binder B and Bach LA: Urokinase type plasminogen activator receptor is involved in insulin-like growth factor-induced migration of rhabdomyosarcoma cells in vitro. J Cell Physiol 197: 131-138, 2003.

25. Gallicchio MA, Kneen M, Hall C, Scott AM and Bach LA: Overexpression of insulin-like growth factor binding protein-6 inhibits rhabdomyosarcoma growth in vivo. Int J Cancer 94: 645-651, 2001

26. Bach LA: Insulin-like growth factor binding protein-6: the 'forgotten' binding protein? Horm Metab Res 31: 226-234, 1999.

27. Chaves $\mathbf{J}$ and Saif MW: IGF system in cancer: from bench to clinic. Anticancer Drugs 22: 206-212, 2011.

28. Kuo YS, Tang YB, Lu TY, Wu HC and Lin CT: IGFBP-6 plays a role as an oncosuppressor gene in NPC pathogenesis through regulating EGR-1 expression. J Pathol 222: 299-309, 2010.

29. Seurin D, Lassarre C, Bienvenu G and Babajko S: Insulin-like growth factor binding protein- 6 inhibits neuroblastoma cell proliferation and tumour development. Eur J Cancer 38: 2058-2065, 2002.

30. Leng SL, Leeding KS, Whitehead RH and Bach LA: Insulin-like growth factor (IGF)-binding protein-6 inhibits IGF-II-induced but not basal proliferation and adhesion of LIM 1215 colon cancer cells. Mol Cell Endocrinol 174: 121-127, 2001.

31. Ricker LJ, Kijlstra A, Kessels AG, et al: Interleukin and growth factor levels in subretinal fluid in rhegmatogenous retinal detachment: a case-control study. PLoS One 6: e19141, 2011.

32. Pennock S and Kazlauskas A: Vascular endothelial growth factor A competitively inhibits platelet-derived growth factor (PDGF)-dependent activation of PDGF receptor and subsequent signaling events and cellular responses. Mol Cell Biol 32: 1955-1966, 2012.

33. Ricker LJ, Dieudonné SC, Kessels AG, et al: Antiangiogenic isoforms of vascular endothelial growth factor predominate in subretinal fluid of patients with rhegmatogenous retinal detachment and proliferative vitreoretinopathy. Retina 32: 54-59, 2012.

34. Liang CM, Tai MC, Chang YH, et al: Glucosamine inhibits epithelial-to-mesenchymal transition and migration of retinal pigment epithelium cells in culture and morphologic changes in a mouse model of proliferative vitreoretinopathy. Acta Ophthalmol 89: e505-e514, 2011.

35. Karthikeyan B, Kalishwaralal K, Sheikpranbabu S, Deepak V, Haribalaganesh R and Gurunathan S: Gold nanoparticles downregulate VEGF-and IL-1 $\beta$-induced cell proliferation through Src kinase in retinal pigment epithelial cells. Exp Eye Res 91: 769-778, 2010.

36. Parrales A, López E and López-Colomé AM: Thrombin activation of PI3K/PDK1/Akt signaling promotes cyclin D1 upregulation and RPE cell proliferation. Biochim Biophys Acta 1813: 1758-1766, 2011. 